\title{
Trends in Tree Diversity and Stand Structure during Restoration: A Case Study in Fragmented Moist Deciduous Forest Ecosystems of Northeast India
}

\author{
Koushik Majumdar, ${ }^{1}$ Uma Shankar, ${ }^{2}$ and Badal Kumar Datta ${ }^{1}$ \\ ${ }^{1}$ Plant Taxonomy and Biodiversity Laboratory, Department of Botany, Tripura University, Suryamaninagar, \\ Tripura 799022, India \\ ${ }^{2}$ Ecosystem Research Laboratory, Centre for Advanced Studies in Botany, School of Life Science, \\ North-Eastern Hill University, Shillong, Meghalaya 793022, India
}

Correspondence should be addressed to Koushik Majumdar; majumdark80@gmail.com

Received 19 December 2013; Accepted 29 May 2014; Published 14 July 2014

Academic Editor: Francisco Arreguin-Sánchez

Copyright (C) 2014 Koushik Majumdar et al. This is an open access article distributed under the Creative Commons Attribution License, which permits unrestricted use, distribution, and reproduction in any medium, provided the original work is properly cited.

Ecological implications for the conservation of fragmented forests to managed local plant diversity have recently drawn much attention of most conservationists. Present study investigates the importance of fragmented forests using different quantitative measures of species diversity and stand structure as indicators of natural restoration from past disturbances. Eleven independent $500 \mathrm{~m} \times 10 \mathrm{~m}$ belt transects $(5.5 \mathrm{ha})$ were established within fragmented low land moist deciduous forests of Tripura. All woody plants $\geq 10 \mathrm{~cm}$ girth at breast height $(\mathrm{GBH})$ were measured. A total of 7,134 individuals with mean density of $648.55 \mathrm{stems} \mathrm{ha}^{-1}$ and $16.36 \mathrm{~m}^{2} \mathrm{ha}^{-1}$ of basal area were recorded, which represented 134 species, 93 genera, and 43 families of woody plants. Diversitydominance curve showed that maximum number of species were ranked $>10$ due to low abundance value. Maximum distributions of stems $(>50 \%)$ were recorded at lowest girth class $(10-30 \mathrm{~cm})$ as an indication of advanced regeneration and significantly declined towards upper girth $\left(r_{\mathrm{adj}}^{2}=0.93 ; P<0.0001\right)$ and height $\left(r_{\mathrm{adj}}^{2}=0.95 ; P<0.0001\right)$ classes, which also indicated that some plants were adopted with ongoing disturbances through both seeded and nonseeded regeneration. Species richness $\left(r_{\text {adj }}^{2}=0.49 ; P=0.05\right)$, dominance $\left(r_{\text {adj }}^{2}=0.68 ; P=0.009\right)$, and density $\left(r_{\text {adj }}^{2}=0.62 ; P=0.02\right)$ were significantly increased at different disturbance intensities. Disturbances strongly influenced typical community association and structure by increasing diversity and population at certain magnitude and thereby showed declining trend towards maturation. Fragmented moist deciduous forests seek immediate attention as they represent spatial habitat for many economical or ecological important species, thus sustaining local biodiversity for livelihoods.

\section{Introduction}

Small forest fragments or areas lying outside fully protected zones maintain a significant number of species and their genetic diversity $[1,2]$. Even forest patches of less than 1 ha in size could play major roles in maintenance of regional biodiversity [3]. During the past several years, large complexes of natural habitat have been converted into agricultural, industrial, or urbanized landscapes, leading to severe loss of the original habitat and an increasing fragmentation of the remnant patches [4]. High fragmentation rate stimulate habitat modifications and the loss of valuable portions of the forest ecosystem, the number of rare and shade - tolerant species increases due to fragmentation especially during recovery at the early successional stage [5]. Tree species with small population will be the first to be lost in the process of forest fragmentation [6]. Tree species diversity is an important and fundamental aspect to total forest ecosystem biodiversity $[7,8]$; they provide resource and habitat for almost all other species [9]. Tree diversity in tropical forests varies greatly from place to place, mainly due to variation in biogeography, climatic responses, habitat suitability, and 
anthropogenic disturbances [10, 11]. Disturbances strongly influence forest dynamics, community attributes, structure, and diversity at both local and regional scales $[12,13]$, evident in changing size class distributions of the most sought-after species [14].

Most of the quantitative vegetation inventories were conducted in species-rich forests and data on species-poor forests or forest fragments are inadequate [15]. In addition, species richness and abundance data are crucial for assessing the impacts of disturbance or fragmentation on local biodiversity, conservation priority setting, and longterm vegetation monitoring [16]. Moist deciduous forest is one of the crucial habitat types of India, and most of the earlier studies were reported from Western Ghats, Eastern Ghats, and Andaman Island [17-20]. Data on community composition and population structure in lowland moist deciduous forests are limited. Since remaining fragmented forests are quickly shrinking or modifying under several manmade influences, immediate attention was felt necessary to gather quantitative inventories for tree diversity and stand structure in fragmented lowland forests to better understand its nature and dynamics. Hence, present objectives were designed to investigate (1) the status of woody plant diversity and structure in fragmented forests, (2) to draw the structural changes under present level of disturbance intensity, and (3) to test the hypothesis that species diversity, stand population, and dominance increased during restoration following intermediate disturbance hypothesis of Connell (1978) [21].

\section{Materials and Methods}

2.1. Study Site. Present study was conducted in Tripura, which is a small hilly state belonging to the northeastern part of India. The state is surrounded by Bangladesh on three sides and only northeast part of the state is connected through Assam and Mizoram with the country, accounting for barely $0.342 \%$ of the total area of the country. In terms of area, it is the third smallest state in the country, after Goa and Sikkim. The geographical area of the state is only $10,492 \mathrm{~km}^{2}$ and has 4 districts. The state is located in biogeographic zone of 9B-North-East hills, endowed with rich and diverse forest resources. About $59.98 \%$ of the geographical area of the state is under the forest. The forests are mainly semievergreen, moist deciduous, mixed sal, and dry deciduous forests. The present study sites located between $23^{\circ} 57^{\prime} 55^{\prime \prime}$ and $24^{\circ} 05^{\prime} 34^{\prime \prime}$ north latitude and $91^{\circ} 17^{\prime} 18^{\prime \prime}$ and $91^{\circ} 29^{\prime} 22^{\prime \prime}$ east longitude. The area is bordered by Bangladesh on northwest side and located in extreme northwest part of state. The study area falls under low physiographic zone: slope is $<40^{\circ}$ and the altitude is $<100 \mathrm{~m}$ (ranging from 18.59 to $90.22 \mathrm{~m}$ amsl). The climate of the area is characterized by highly humid atmosphere and temperatures range from $10^{\circ} \mathrm{C}$ to $35^{\circ} \mathrm{C}$. The monsoon season is mainly from June to September with an annual average rainfall around $2400 \mathrm{~mm}$ mostly due to southwest monsoon. Forest characteristic of the study area is similar to moist deciduous forest $\left(\mathrm{I} / \mathrm{I} /{ }_{3} \mathrm{C} / \mathrm{C}_{3} \mathrm{~b}\right)$. Total forest area recorded for West Tripura is $1155.409 \mathrm{~km}^{2}$ out of $6292.681 \mathrm{~km}^{2}$. Actual study locations belong to Mohanpur and Hezamara block

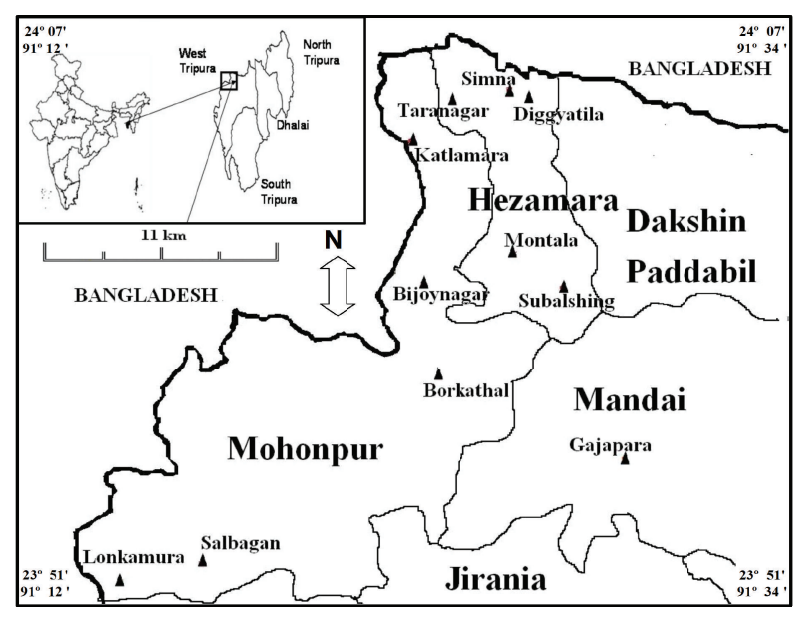

FIGURE 1: Map of the study area showing eleven different sites in fragmented forests of West Tripura, India.

under Sadar forest division of West Tripura (Figure 1). North part of this area particularly the Hezamara block inhabited by Tripura and Reang tribe, many of them still practicing traditional shifting cultivation. Hence, both the marginal and interior forest areas are under threat of sever degradation. Large forest areas have been converted from time to time into tea plantation especially in Mohanpur block and only few forest patches still exist [22].

2.2. Field Sampling. Eleven 0.5 ha belt transects $(500 \mathrm{~m} \times$ $10 \mathrm{~m}$ ) were established in the inventory of woody vegetation of fragmented moist deciduous forest of West Tripura district during April 2011, and thus the total sampling area was 5.5 ha (Table 1(A)). Plots were laid randomly within remaining fragmented forests surrounding village boundary, plantation, and roads. In each plot, all woody plants $\geq 10 \mathrm{~cm}$ girth at breast height $(\mathrm{GBH})$ were measured in centimeter and counted individually at $1.3 \mathrm{~m}$ height from the ground level using a tape; height for all individuals was measured to the nearest meter [23]. We restricted our analysis and interpretation of diversity and community composition to species that had successfully established a minimum girth class. We also included those woody shrubs, bamboos, and lianas that attained our girth category. The GPS locations of the plots and physical condition of every individual were noted under alive, cut, and dead categories; sites disturbance scores were also recorded to obtain quantitative disturbance intensity $[24,25]$. Specimens were identified with the help of the Flora of Tripura State and the Flora of Assam [26, 27]. The reference herbarium was deposited in herbarium of Botany Department, Tripura University.

2.3. Data Analysis. The field data was analyzed for number of species and quantitative analysis of frequency; density per ha and basal area per ha and their relative values were calculated and summed to get Importance Value Index (IVI) using Mueller-Dombois and Ellenberg [28]. Relative density $=($ Density of the species/Total density of all species $) \times 100$. 


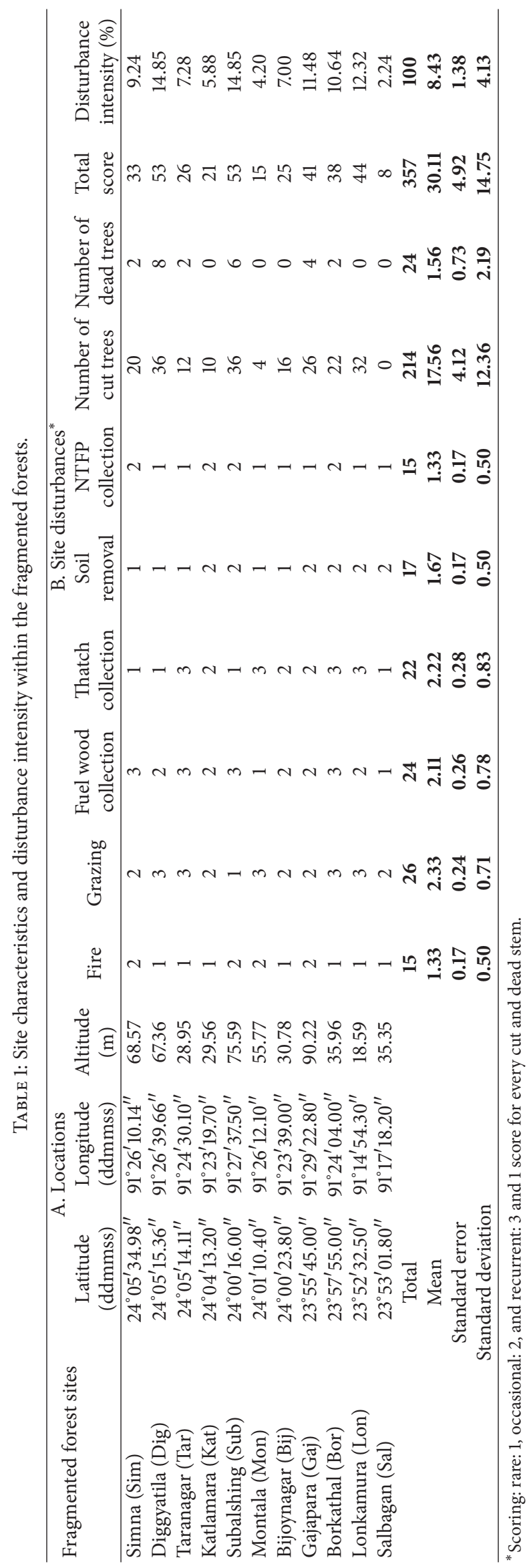


Relative frequency $=($ Frequency of the species $/$ Total frequency of all species $) \times 100$. Relative dominance $=($ Basal area of the species/Total basal area for all species) $\times 100$. Important Value Index (IVI) = Relative Frequency + Relative Density + Relative Basal Area. General diversity was calculated using Shannon and Wiener index [29] and the index of dominance of the community was calculated by Simpson's index [30]. Shannon and Wiener's index $=-\sum\left\{(n i / N) \log _{2}(n i / N)\right\} ; n i=$ IVI of the species $i, N=$ IVI of all species in the community. Simpson dominance index $=\sum\left\{(n i / N)^{2}\right\} ; n i=$ IVI of species $i, N=$ IVI of all species in the community. Species richness index was computed using Menhinick [31] and Evenness index of the forest community was calculated following Pielou [32]. Menhinick richness index $=S / \sqrt{N} ; S=$ total number of species, $N=$ total number of individuals. Pielou evenness index $=$ Shannon and Wiener's index $/ \log (S) ; S=$ total number of species.

The number of species was plotted on $y$-axis against the number of individuals on the $x$-axis for comparing species richness among the fragmented forests [33] and species abundance data was plotted against species rank to develop diversity versus dominance curves [34], using BioDiversity Pro version 2 [35]. Woody species was grouped among ten girth classes $(\geq 10-<30,30-<60,60-<90,90-<120,120-<150$, $150-<180,180-<210,210-<240,240-<270$, and $>270 \mathrm{~cm})$ and height classes $(<3,3-<6,6-<9,9-<12,12-<15,15-<18,18-<21$, $21-<23,24-<26$, and $>26 \mathrm{~m}$ ) to observe the distribution of population at different age and height classes. To examine the pattern of changes in community types and stand structure across the studied sites, regression curve fitting was used with midvalue of overall stem density ha ${ }^{-1}$ girth and height classes on $x$-axis and $\log$ transformed density ha ${ }^{-1}$ on $y$-axis [36]. In addition to test intermediate disturbance hypothesis, we examined the relationship by curve fitting between density, diversity, and dominance on $y$-axis and disturbance intensity on $x$-axis for those fragmented forests using Origin and PAST software [37, 38].

\section{Results}

3.1. Status of Species Richness and Habitat Diversity Attributes. A total of 134 woody species $(\geq 10 \mathrm{~cm} \mathrm{GBH})$ representing 93 genera and 43 families were recorded within 5.5 ha fragmented moist deciduous forest of West Tripura. Habitwise, out of 134 woody species 118 species $(88.06 \%)$ were trees, $7(5.22 \%)$ species were woody liana, $4(2.99 \%)$ species were woody shrub, and $5(3.73 \%)$ species were bamboo. Species richness ranged from 31 to 61 species in eleven sites. Both Dig and Gaj had 61 species, which was two times greater than $\mathrm{Sal}$ (31). The observed family richness was the greatest in Gaj (37). The rarefaction curves confirmed that sites Gaj, Sim Dig, and Kat were steeper than the others, suggesting high species richness (Figure 2). Whereas Sim did not asymptote at similar numbers of individual, which revealed that sufficient number of species might not covered by our sampling effort and there was possibility to get additional species in Sim compared to other sites. Gaj scored high value of Shannon diversity index (3.92), while Sal recorded low value (2.20) compared to the

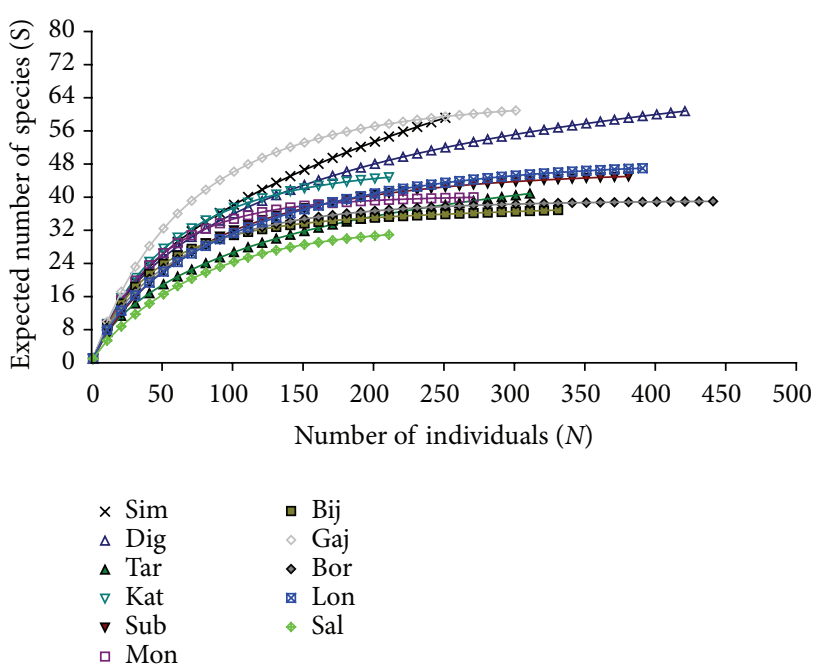

FIGURE 2: Rarefaction curves for comparing the species richness in eleven fragmented forest stands.

rest of the sites. Mean Simpson dominance index was 0.06 and was recorded high in Sub (0.07), which was recorded low in Gaj (0.02). Species were more evenly distributed in Sim, Tar, Gaj, and Mon, with a mean value of Evenness index of 1.94 (range 1.47-2.16), while Menhinik's species richness varied from 1.31 to 2.64 along the fragment sites with mean value of 1.85 (Table 2 ).

The diversity-dominance curve displayed a log series distribution where species ranked (1-100) from most to least abundant, and majority of the species had lower abundance and population, while few species showed higher values. Tectona grandis appeared to be the most abundant in Sim, Sub, and Mon; Schima wallichii in Dig, Kat, and Gaj; Syzygium cerasoides in Bij and Bor; and Microcos paniculata, Gmelina arborea, and Shorea robusta in Tar, Lon, and Sal, respectively. Holarrhena antidysenterica, Microcos paniculata, Terminalia bellirica, Glochidion multiloculare, Chaetocarpus castanicarpus, Syzygium cerasoides, and Ziziphus rugosa were observed as codominant association, although Aporosa obovata, Canthium glabrum, Desmos dumosus, Elaeocarpus prunifolia, Elaeocarpus robustus, Bhesa robusta, Leea guineensis, Litsea cubeba, and Litsea laeta were recorded with very low abundance and population (Figure 3).

3.2. Patterns of Stand Density, Basal Area, and Important Value Index (IVI). A total of 7,134 individuals were encountered with mean density of 648.55 trees ha $^{-1}$ (ranged from 428 to $884 \mathrm{ha}^{-1}$ ) in eleven $0.5 \mathrm{ha}$ of fragmented forest sites. The highest woody density was recorded for Bor $\left(884 \mathrm{ha}^{-1}\right)$ and lowest for Sal $\left(428 \mathrm{ha}^{-1}\right)$. Top ten dominant trees, namely, Microcos paniculata $\left(43.82 \mathrm{ha}^{-1}\right)$, Tectona grandis $\left(43.09 \mathrm{ha}^{-1}\right)$, Holarrhena antidysenterica $\left(30.36 \mathrm{ha}^{-1}\right)$, Syzygium cerasoides $\left(27.64 \mathrm{ha}^{-1}\right)$, Shorea robusta $\left(24.91 \mathrm{ha}^{-1}\right)$, Schima wallichii $\left(23.45 \mathrm{ha}^{-1}\right)$, Syzygium fruticosum (21.45 ha $\left.{ }^{-1}\right)$, Melocanna baccifera $\left(17.82 \mathrm{ha}^{-1}\right)$, Gmelina arborea $\left(17.45 \mathrm{ha}^{-1}\right)$, and Terminalia bellirica $\left(16.55 \mathrm{ha}^{-1}\right)$, 
TABLE 2: Consolidated details of woody plant diversity inventory ( $\geq 10 \mathrm{~cm} \mathrm{GBH})$ in eleven fragmented moist deciduous forests of Tripura.

\begin{tabular}{|c|c|c|c|c|c|c|c|c|c|c|c|c|c|c|}
\hline \multirow{2}{*}{ Parameters } & \multicolumn{11}{|c|}{ Fragmented forest sites } & \multirow{2}{*}{ Mean } & \multirow{2}{*}{ Standard error } & \multirow{2}{*}{ Standard deviation } \\
\hline & Sim & Dig & Tar & Kat & Sub & Mon & $\mathrm{Bij}$ & Gaj & Bor & Lon & Sal & & & \\
\hline Number of woody species & 60 & 61 & 41 & 45 & 45 & 40 & 37 & 61 & 39 & 47 & 31 & 46.09 & 3.11 & 10.32 \\
\hline Number of genera & 50 & 54 & 31 & 42 & 39 & 37 & 29 & 54 & 33 & 41 & 31 & 40.09 & 2.76 & 9.16 \\
\hline Number of families & 29 & 32 & 22 & 26 & 32 & 28 & 23 & 37 & 25 & 28 & 25 & 27.91 & 1.34 & 4.44 \\
\hline Shannon index & 3.73 & 3.57 & 3.33 & 3.49 & 3.32 & 3.47 & 2.75 & 3.92 & 2.58 & 3.38 & 2.2 & 3.25 & 0.16 & 0.52 \\
\hline Simpson index & 0.03 & 0.04 & 0.05 & 0.04 & 0.07 & 0.04 & 0.02 & 0.02 & 0.02 & 0.06 & 0.3 & 0.06 & 0.02 & 0.08 \\
\hline Evenness index & 2.1 & 2 & 2.06 & 2.1 & 2.01 & 2.16 & 1.64 & 2.2 & 1.62 & 2.01 & 1.47 & 1.94 & 0.07 & 0.25 \\
\hline Richness index & 2.64 & 2.08 & 1.64 & 2.2 & 1.63 & 1.7 & 1.42 & 2.47 & 1.31 & 1.71 & 1.5 & 1.85 & 0.13 & 0.44 \\
\hline Density $\left(\mathrm{ha}^{-1}\right)$ & 518 & 854 & 628 & 436 & 762 & 552 & 680 & 608 & 884 & 784 & 428 & 648.55 & 47.87 & 158.78 \\
\hline Basal area $\left(\mathrm{m}^{2} \mathrm{ha}^{-1}\right)$ & 5.28 & 14.08 & 6.8 & 14.5 & 12.55 & 9 & 16.44 & 23.6 & 14.04 & 16.6 & 47.08 & 16.36 & 3.43 & 11.37 \\
\hline
\end{tabular}

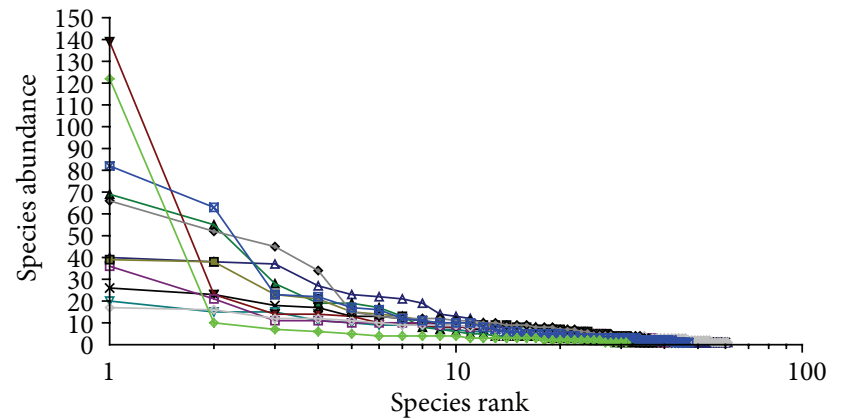

$\begin{array}{ll}\times \text { Sim } & \square \mathrm{Bij} \\ \triangle \mathrm{Dig} & \diamond \mathrm{Gaj} \\ \triangle \mathrm{Tar} & \diamond \mathrm{Bor} \\ \nabla \mathrm{Kat} & \otimes \text { Lon } \\ \nabla \mathrm{Sub} & \star \text { Sal } \\ \square \text { Mon } & \end{array}$

FIGURE 3: Diversity-dominance curve and species ranking based on species abundance.

contributed in $41.10 \%$ of overall density. Mean basal area was $16.36 \mathrm{~m}^{2} \mathrm{ha}^{-1}$ for the whole study of which top ten dominant trees grasped $9.44 \mathrm{~m}^{2} \mathrm{ha}^{-1}(57.68 \%)$ of total basal area and it recorded the minimum for $\operatorname{Sim}\left(5.28 \mathrm{~m}^{2} \mathrm{ha}^{-1}\right)$ and was the greatest in case of Sal $\left(47.08 \mathrm{~m}^{2} \mathrm{ha}^{-1}\right)$. Based on the IVI, top ten dominant and codominant trees contributed in 110.11 of total IVI (300). Shorea robusta grasps the maximum IVI (30.53), which was predominant only in Sal, followed by Tectona grandis (11.70), Microcos paniculata (11.22), Schima wallichii (10.20), Syzygium cerasoides (9.80), Holarrhena antidysenterica (8.15), Artocarpus heterophyllus (7.54), and Terminalia bellirica (7.12). While 18 species sowed IVI value $<0.30$, Desmos dumosus, Leea aequata, Elaeocarpus robustus, and Actinodaphne obovata were recorded with very low IVI contribution to the fragmented forest. Overall 27 species were selected (top five most dominant species from each site) based on their IVI contribution to those fragmented forests, which suggested that Microcos paniculata, Holarrhena antidysenterica, Chaetocarpus castanicarpus, Glochidion multilocure, Syzygium cerasoides, and Ziziphus rugosa were increasing their IVI over previously predominant trees. These small tress species showed very little differences in terms of IVI contribution with key dominant species, namely, Shorea robusta, Schima wallichii, Tectona grandis, and Gmelina arborea (Figure 4).

3.3. Changes in Girth or Age-Class and Height-Class Distributions. Stem density across girth classes in all sites decreases almost from smallest to largest trees. While occurrences of mean stems ha ${ }^{-1}$ at lower girth class $(10-<30 \mathrm{~cm})$ were $50.88 \%(330 \pm 9.54)$, followed by $29.10 \%(188.73 \pm 96.94)$ in $30-<60 \mathrm{~cm}$ girth class and $10.96 \%(71.09 \pm 37.98)$ in $60-$ $<90 \mathrm{~cm}$ girth class, only $0.06 \%$ stems were shown in the highest $(240-<300 \mathrm{~cm})$ girth classes. Maximum number of individuals at lower girth class was recorded for Bor (468) and minimum for both Kat and Gaj (212). While few individuals were recorded at higher girth class $(>270 \mathrm{~cm})$, some higher girth classes were absent in Sim, Tar, Sub, Mon, Bor, and Lon. Stems were more frequently distributed in all the eleven sites within the $10-<120 \mathrm{~cm}$ girth classes. The overall stem density $\mathrm{ha}^{-1}$ at different age classes was significant $\left(r_{\text {adj }}^{2}=\right.$ $0.93 ; P<0.0001)$ among the studied sites and showed inverse quadratic relationship (Figure 5). The distribution of stems by height class intervals showed that maximum trees $(82.47 \%)$ were widely distributed within 3-12 $\mathrm{m}$ range; $31.46 \%$ of individuals were $>3 \mathrm{~m}$, followed by $23.63 \%$ between 3 and $<6 \mathrm{~m}$ and $14.35 \%$ within $6-<9 \mathrm{~m}$, whereas $7.20 \%$ of individuals distributed between 12 and $<15 \mathrm{~m}$, only $0.42 \%$ individuals were attained $>26 \mathrm{~m}$. Density of trees was linearly declined across the height classes $\left(r_{\mathrm{adj}}^{2}=0.95 ; P<0.0001\right)$ among the fragmented sites (Figure 6).

3.4. Effects of Disturbances and Recovery Processes. Besides serious past logging experience for timber, several other anthropogenic disturbances were still ongoing in those fragmented forests sites. Grazing and fuelwood collection were more intense due to closeness of village. A total of 214 trees ha ${ }^{-1}(19.45 \pm 12.36)$ were recorded as cut or logged and 24 trees ha $^{-1}(2.18 \pm 2.75)$ as injured out of overall 7,134 individuals; maximum number of cut and injured trees were recorded both from Dig and Sub. Both cut and injured trees were $238(21.64 \pm 14.50)$ for overall study but were absent in case of Sal. Site disturbance intensity was obtained 


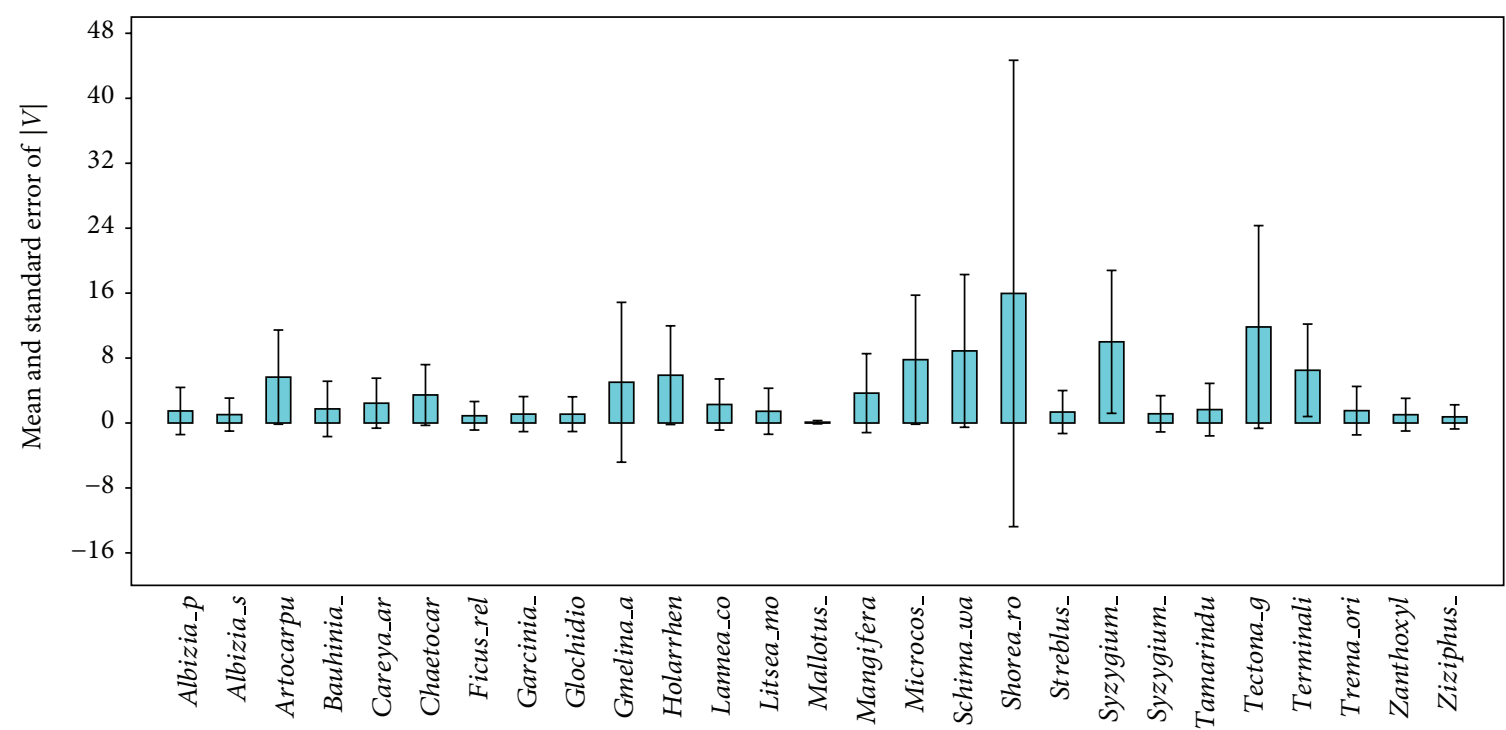

FIGURE 4: Dominance and codominance competition of 27 tree species (mean and standard error of IVI). Five most dominant species were selected from each fragmented forest site based on highest IVI contribution to the community.

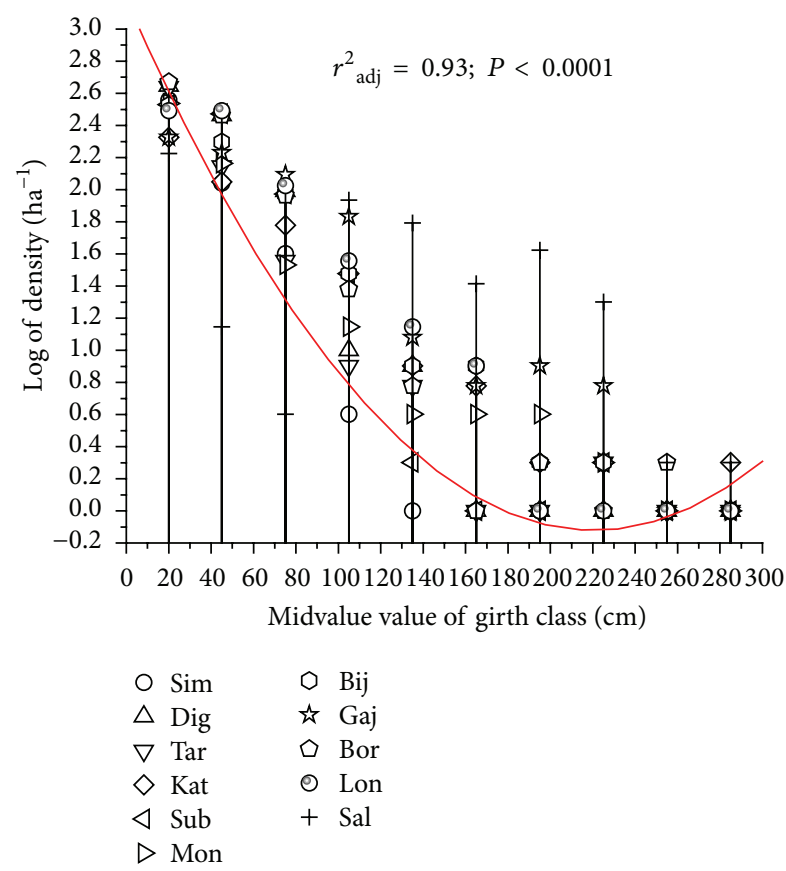

FIGURE 5: Relationship between population density (log transformed) and midvalue of girth class intervals across the fragmented forest sites.

qualitatively by summing the disturbance scores along and the number of cut and injured individuals (Table 1(B)). It could be assumed that the proportion of scores that showed maximum value revealed comparatively high level of anthropogenic disturbance or fragmentation than the lower value. The highest intensity was recorded for Sub and Dig (14.85\%), followed by Lon (12.32\%), Gaj (11.48\%), and Bor (10.46\%), and the lowest in case of Sal $(2.24 \%)$. While the number

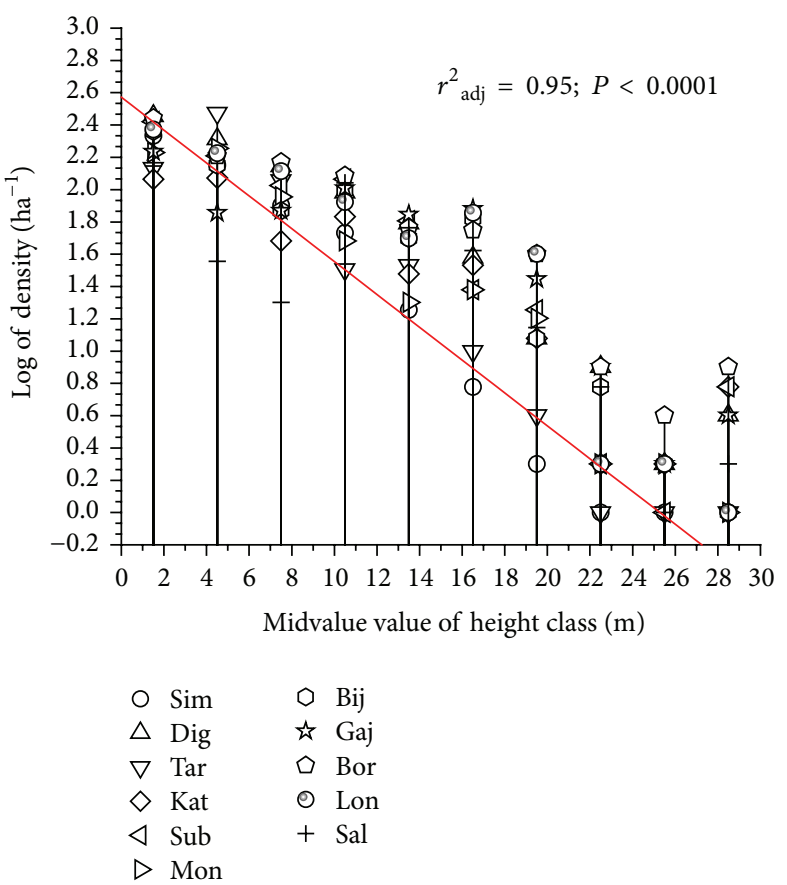

FIGURE 6: Relationship between population density (log transformed) and midvalue of height class intervals across the fragmented forest sites.

of species (that occurred on each site) was significantly increased with disturbance intensity $\left(\chi^{2}=0.06 ; F=3.92\right.$; $P=0.05)$ at $15 \%$ level and declining trend was observed when intensity level was increased among the sites (Figure 7), initially, declining trend of the dominance of key community species was observed, and at midlevel of disturbance $(10 \%)$ few fragmentation tolerant species significantly $\left(\chi^{2}=0.36 ; F\right.$ $=8.72, P=0.009)$ increased in dominance with disturbance 


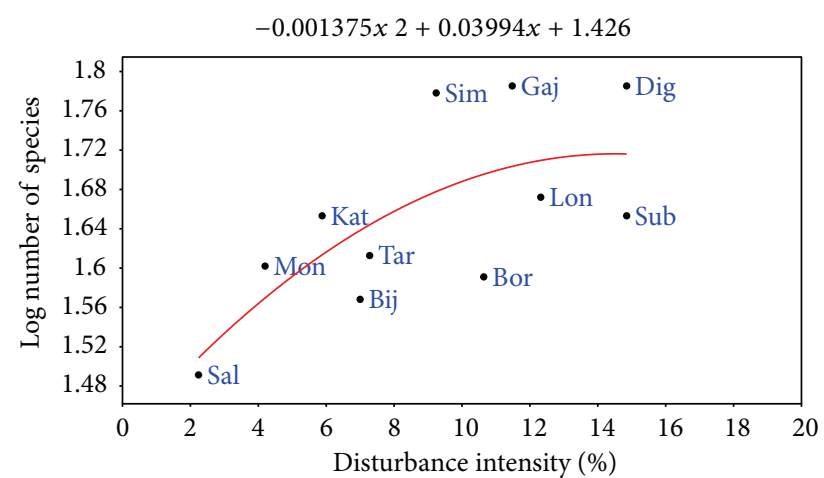

FIGURE 7: Relationship between species richness and disturbance intensity.

intensity (Figure 8). In addition, relationship between stem density and disturbance intensity also suggested that present number of stems per ha were increased significantly with fragmentation intensity $\left(\chi^{2}=0.05 ; F=6.65 ; P=0.02\right)$ during restoration (Figure 9).

\section{Discussion}

Rarefaction curves suggested that the maximum number of species was counted for Gaj, Sim, and Dig, while Sim did not show asymptote and species richness was much lower in the relatively managed Sal forest. Higher species richness in the fragmented sites might attribute to intermediate disturbance hypothesis [21]. Species richness might be enhanced in some of the sites through quick accumulation of some locally adaptable early successional species. The range of species richness (31-61) recorded within the present study was more than Puerto Rico, 30-35 species [39], and moist deciduous forest of Western Ghats was 24-26 species [40]. However, overall 134 species encountered in this inventory were higher than the number of species reported from some well-protected Indian forests [41-43]. The value of Shannon-Winner diversity index ranged from 2.20 to 3.92; whereas this value generally ranges between 0.83 and 4.1 for Indian forests [41], hence, present studies' value was fallen within the reported range. Species diversity was increased in case of Gaj, Sim, Dig, Lon, and Sub (Figure 7) along the disturbance intensity $\left(r_{\text {adj }}^{2}=0.49 ; P=0.05\right)$ because diversity in communities increases under intermediate disturbance regime [21]. Instead of protection and management in Sal by Forest Department, it showed minimum species richness, which might be due to presence of high density of voluminous S. robusta, which generally has strong competitive effects on seedling growth and regeneration of other species [36, 42]. However, disturbances allow species to grow well in new environment, recruited and established by increasing the number of species that are not found in managed areas [43]; hence, species richness fairly increased in those fragmented forests.

Stem density ha ${ }^{-1}$ at $\geq 10 \mathrm{~cm}$ girth class in tropical forest generally varies from 245 to 859 trees ha $^{-1}$ [44, 45]; present

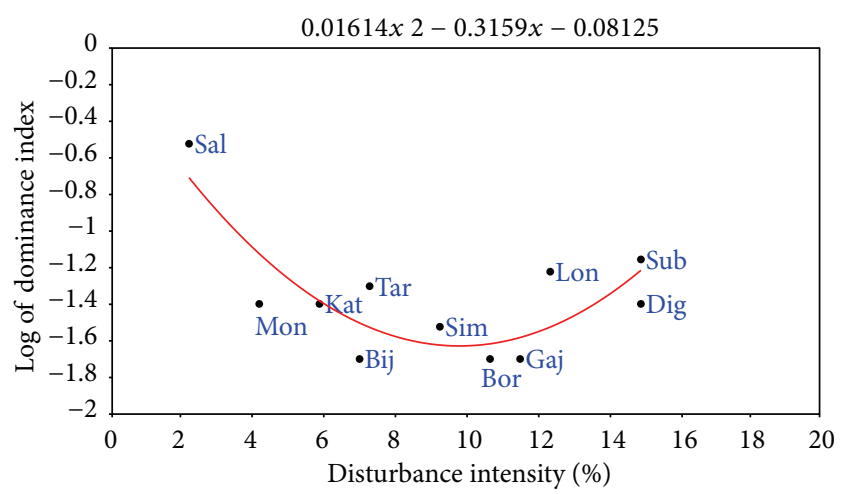

FIGURE 8: Relationship between species dominance and disturbance intensity.

mean stand density of 648.55 trees ha $^{-1}$ (range $428-884 \mathrm{ha}^{-1}$ ) was observed higher than protected Western Ghats moist deciduous forest $[46,47]$. Such relatively higher density of the present fragmented forests might be due to their patchy condition which resulted from past disturbances, since the trend of smaller trees' density was reported to increase after historic disturbances [48]. Significant inverse relation of overall stem density-age classes suggested that $50.88 \%$ of stems were at lower girth classes, that is, $10-<30 \mathrm{~cm}$ (Figure 5) which was the indication of advance regeneration stages and possibly those small fragmented forests were recuperating from past disturbances. 214 trees ha $^{-1}$ were recorded as logged or cut in the whole study, which also suggested illegal logging and heavy timber requirements. Lower abundance or absence of upper canopy forming or old mature trees was also evident from overall stem densityheight classes (Figure 6) and so forth, which might result in enough gaps or forest openings, where fragmentation tolerant small tree species were facilitated to regenerate quickly and increase in their stem density $[36,42]$. After removal of mature or old aged key dominant tree species especially for timber, many opportunistic species might gather through seeded or nonseeded multiplication in absence of previously key dominant species. Hence, stem density was significantly increased with disturbance intensity $\left(r_{\text {adj }}^{2}=0.62 ; P=0.02\right)$ in those sites as an early successional stage and the trend possibly declined very slowly from this level towards forest maturation (Figure 9).

Mean basal area value of $16.36 \mathrm{~m}^{2} \mathrm{ha}^{-1}$ obtained in the present study (range $5.28-47.08 \mathrm{~m}^{2} \mathrm{ha}^{-1}$ ) was close to moist deciduous forests of Western Ghats $14.7 \mathrm{~m}^{2} \mathrm{ha}^{-1}$ and $12.83 \mathrm{~m}^{2} \mathrm{ha}^{-1}[46,47]$ and was less than $49 \mathrm{~m}^{2} \mathrm{ha}^{-1}$ in tropical moist deciduous forest of Eastern Ghats [49]. Dominance and codominance association in those fragmented forest suggested that S. robusta, T. grandis, S. wallichii, and so forth still have the control over upper canopy structure and basal area. But simultaneously locally adapted small oligarchic species were increasing their population density to keep the codominant rank by maximum IVI contribution, which might lead to the variation in community association over existing forest structure by shifting of codominant species 


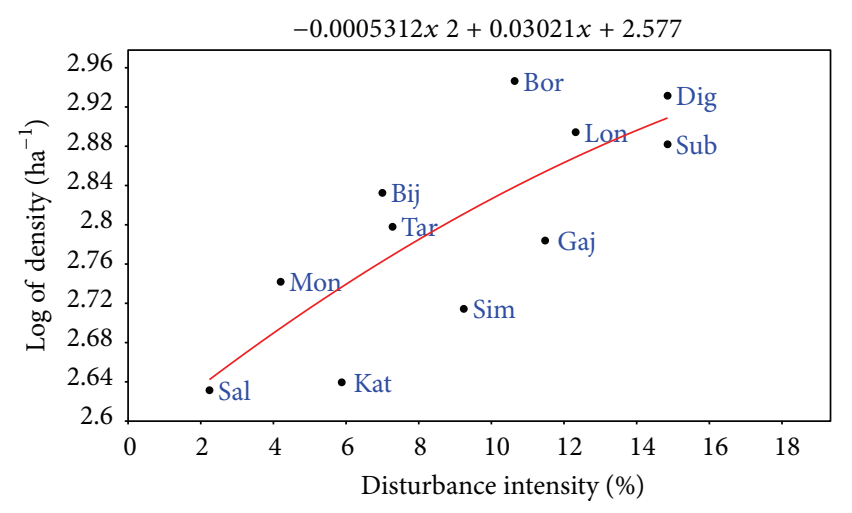

FIGURE 9: Relationship between stem density and disturbance intensity.

into the most dominant species rank at such intensity of disturbances (Figure 4 ). Species dominance generally increases as a function of stress or past disturbance [50], and these species have vital role in the microenvironment within the community [51]. Higher abundance of several local oligarchic small tree species as codominant associations in those fragmented forests was increased dominance especially in case of Sub, Lon, and Dig (Figure 8) due to strong adaptability of those species with fragmentation intensity $\left(r_{\mathrm{adj}}^{2}=0.68\right.$; $P=0.009)$. The intensity of disturbances greatly influenced species dominance in those fragmented forests which may affect future forest structure and composition, succession phases, and species restoration. Fragmentation may establish several transitional community associations which are mostly dominated by few local adaptable species through direct or indirect competitions through increasing IVI over previously key dominated species.

\section{Conclusions}

Bamboo shared $91.25 \%$ of overall IVI of the present fragmented forest, which contributed enormously in rural livelihood by fulfilling the NTFPs and fuelwood demand for the people living proximate of those fragmented forests. Many bamboo patches were dried due to flowering especially in Melocanna baccifera, Bambusa balcooa, and B. tulda which in turn drastically changed the trend of demands for forest resources in those fragmented forests. Demands for fuelwoods, thatches, and structural and fencing materials were more or less likely to shift into the small and medium sized trees in absence of bamboo in those fragmented forests (after flowering), which may further influence the natural process of restoration in those fragmented forests, may restrict the possibilities of species richness, and locally enhance the process of either species monodominance or rareness. Fragmented forest plays a crucial role for conservation and sustaining local plant genetic diversity, which may be the only remaining store for many natural products and threatened species beyond protected areas. Monitoring of fragmented tree species and plantation of locally prioritized species in the opened patches will contribute towards effective management between forest dependent people and fragmented forests.

\section{Conflict of Interests}

The authors declare that there is no conflict of interests regarding the publication of this paper.

\section{Acknowledgments}

The authors are thankful to Department of Biotechnology (DBT), Government of India, for funding received through DBT Network Project (BT/PR7928/NDB/52/9/2006). The authors also thank Professor S. Sinha, H.O.D., Department of Botany, Tripura University, for his valuable suggestions and facilities. Thanks also are extended to Sri Samir Kumar Debnath and Sri Monthosh Roy for their consistent field assistance and several anonymous reviewers.

\section{References}

[1] I. M. Turner, H. T. W. Tan, Y. C. Wee, A. B. Ibrahim, P. T. Chew, and R. T. Corlett, "A study of plant species extinction in Singapore: lessons for the conservation of tropical biodiversity," Conservation Biology, vol. 8, no. 3, pp. 705-712, 1994.

[2] M. B. Mulder and P. Coppolillo, Conservation: Linking Ecology, Economics, and Culture, Princeton University Press, Princeton, NJ, USA, 2005.

[3] R. Pither and M. Kellman, "Tree species diversity in small, tropical riparian forest fragments in Belize, Central America," Biodiversity and Conservation, vol. 11, no. 9, pp. 1623-1636, 2002.

[4] H. Jacquemyn, J. Butaye, and M. Hermy, "Influence of environmental and spatial variables on regional distribution of forest plant species in a fragmented and changing landscape," Ecography, vol. 26, no. 6, pp. 768-776, 2003.

[5] J. L. Hill and P. J. Curran, "Species composition in fragmented forests: conservation implications of changing forest area," Applied Geography, vol. 21, no. 2, pp. 157-174, 2001.

[6] H. Zhu, Z. F. Xu, H. Wang, and B. G. Li, “Tropical rain forest fragmentation and its ecological and species diversity changes in southern Yunnan," Biodiversity and Conservation, vol. 13, no. 7, pp. 1355-1372, 2004.

[7] K. Rennolls and Y. Laumonier, "Species diversity structure analysis at two sites in the tropical rain forest of Sumatra," Journal of Tropical Ecology, vol. 16, no. 2, pp. 253-270, 2000.

[8] W. Huang, V. Pohjonen, S. Johansson, M. Nashanda, M. I. L. Katigula, and O. Luukkanen, "Species diversity, forest structure and species composition in Tanzanian tropical forests," Forest Ecology and Management, vol. 173, no. 1-3, pp. 11-24, 2003.

[9] C. H. Cannon, D. R. Peart, and M. Leighton, "Tree species diversity in commercially logged Bornean rainforest," Science, vol. 281, no. 5381, pp. 1366-1368, 1998.

[10] T. C. Whitmore, An Introduction to Tropical Rain Forests, Oxford University Press, Oxford, UK, 1993.

[11] M. A. Hare, D. O. Lantagne, P. G. Murphy, and H. Checo, "Structure and tree species composition in a subtropical dry forest in the Dominican Republic: comparison with a dry forest in Puerto Rico," Tropical Ecology, vol. 38, no. 1, pp. 1-17, 1997. 
[12] S. P. Hubbell, R. B. Foster, S. T. O’Brien et al., "Light-gap disturbances, recruitment limitation, and tree diversity in a neotropical forest," Science, vol. 283, no. 5401, pp. 554-557, 1999.

[13] O. I. Sumina, "Plant communities on anthropogenically disturbed sites on the Chukotka Peninsula, Russia," Journal of Vegetation Science, vol. 5, no. 6, pp. 885-896, 1994.

[14] E. J. Luoga, E. T. F. Witkowski, and K. Balkwill, "Regeneration by coppicing (resprouting) of miombo (African savanna) trees in relation to land use," Forest Ecology and Management, vol. 189, no. 1-3, pp. 23-35, 2004.

[15] M. Johnston and M. Gillman, "Tree population studies in lowdiversity forests, Guyana. I. Floristic composition and stand structure," Biodiversity and Conservation, vol. 4, no. 4, pp. 339362, 1995.

[16] A. S. van Jaarsveld, S. Freitag, S. L. Chown et al., "Biodiversity assessment and conservation strategies," Science, vol. 279, no. 5359, pp. 2106-2108, 1998.

[17] S. M. Sundarapandian and P. S. Swamy, "Plant biodiversity at low-elevation evergreen and moist deciduous forests at Kodayar (W. Ghats, India)," International Journal of Ecology and Environmental Sciences, vol. 23, no. 4, pp. 363-379, 1997.

[18] U. Ghate, N. V. Joshi, and M. Gadgil, "On the patterns of tree diversity in the Western Ghats of India," Current Science, vol. 75, no. 6, pp. 594-603, 1998.

[19] H. Padalia, N. Chauhan, M. C. Porwal, and P. S. Roy, "Phytosociological observations on tree species diversity of Andaman Islands, India," Current Science, vol. 87, no. 6, pp. 799-806, 2004.

[20] A. Sen, T. Johri, and N. S. Bisht, "Analysis of the effects of anthropogenic interferences on tree species composition in the forests of Dadra and Nagar Haveli, India," Current Science, vol. 95, no. 1, pp. 50-58, 2008.

[21] J. H. Connell, "Diversity in tropical rain forests and coral reefs," Science, vol. 199, no. 4335, pp. 1302-1310, 1978.

[22] Anonymous., The State of Forest Report, Forest Survey of India, Dehradun, India, 2009.

[23] U. Shankar, "A case of high tree diversity in a sal (Shorea robusta)-dominated lowland forest of Eastern Himalaya: floristic composition, regeneration and conservation," Current Science, vol. 81, no. 7, pp. 776-786, 2001.

[24] P. Rao, S. K. Barik, H. N. Pandey, and R. S. Tripathi, "Community composition and tree population structure in a sub-tropical broad-leaved forest along a disturbance gradient," Vegetatio, vol. 88, no. 2, pp. 151-162, 1990.

[25] S. Mani and N. Parthasarathy, "Tree diversity and stand structure in inland and coastal tropical dry evergreen forests of peninsular India," Current Science, vol. 90, no. 9, pp. 1238-1246, 2006.

[26] D. B. Deb, The Flora of Tripura State, vol. 1-2, Today and Tomorrow's Printers and Publishers, New Delhi, India, 1981.

[27] U. N. Kanjilal, P. C. Kanjilal, A. Das, R. N. de, and N. L. Bor, Flora of Assam, vol. 1-5, Government Press, Shillong, India, 1940.

[28] D. Muller-Dombois and H. Ellenberg, Aims and Methods of Vegetation Ecology, John Wiley and Sons, 1974.

[29] C. E. Shannon and W. Wiener, The Mathematical Theory of Communities, University of Illinois Press, Urbana, Ill, USA, 1963.

[30] E. H. Simpson, "Measurement of diversity," Nature, vol. 163, article 688, 1949.

[31] E. F. Menhinick, "A comparison of some speciesindividuals diversity indices applied to samples of field insects," Ecology, vol. 45, pp. 859-861, 1964.
[32] T. Ganesh, R. Ganesan, M. Soubadra Devy, P. Davidar, and K. S. Bawa, "Assessment of plant biodiversity at a mid-elevation evergreen forest of Kalakad-Mundanthurai Tiger Reserve, Western Ghats, India," Current Science, vol. 71, no. 5, pp. 379-392, 1996.

[33] D. Simberloff, "Properties of the rarefaction diversity measurement," The American Naturalist, vol. 106, pp. 414-418, 1972.

[34] K. M. Shaw, P. J. D. Lambshead, and H. M. Platt, "Detection of pollution induced disturbance in marine benthic assemblages with special reference to nematodes," Marine Ecology Progress Series, vol. 11, pp. 195-202, 1983.

[35] N. McAleece, J. D. G. Gage, P. J. D. Lambshead, and G. L. J. Paterson, BioDiversity Professional Statistics Analysis Software, Scottish Association for Marine Science and the Natural History Museum, London, UK, 1997.

[36] I. P. Sapkota, M. Tigabu, and P. C. Odén, "Spatial distribution, advanced regeneration and stand structure of Nepalese Sal (Shorea robusta) forests subject to disturbances of different intensities," Forest Ecology and Management, vol. 257, no. 9, pp. 1966-1975, 2009.

[37] Origin 2013, Free version, OriginLab Corporation, http://www.originlab.com/.

[38] O. Hammer, D. A. T. Harper, and P. D. Ryan, "PAST: paleontological statistics software package for education and data analysis, version 2.03," Paleontologia Electronica, vol. 4, no. 1, p. 9, 2001.

[39] P. G. Murphy and A. E. Lugo, "Ecology of tropical dry forest.," Annual Review of Ecology and Systematics, vol. 17, pp. 67-88, 1986.

[40] N. I. Valappil and K. Swarupanandan, "Regeneration dynamics and sylvigenesis in the moist deciduous forests of southwest India," New Forests, vol. 11, no. 3, pp. 185-205, 1996.

[41] N. Parthasarathy, V. Kinhal, and L. Praveenkumar, “ Plant species diversity and human impacts in the tropical wet evergreen forests of southern Western Ghats," in Proceedings of the Indo-French Workshop on Tropical Forest Ecosystems: Natural Functioning and Anthropogenic Impact, French Institute, Pondicherry, India, November 1992.

[42] S. K. Pandey and R. P. Shukla, "Plant diversity in managed sal (Shorea robusta Gaertn.) forests of Gorakhpur, India: species composition, regeneration and conservation," Biodiversity and Conservation, vol. 12, no. 11, pp. 2295-2319, 2003.

[43] T. Banda, W. Schwartz, and T. M. Caro, "Woody vegetation structure and composition along a protection gradient in a miombo ecosystem of Western Tanzania," Forest Ecology and Management, vol. 230, no. 1-3, pp. 179-185, 2006.

[44] P. S. Ashton, "A quantitative phytosociological technique applied to tropical mixed rain forest vegetation," Malayan Forester, vol. 27, pp. 304-317, 1964.

[45] D. G. Campbell, J. L. Stone, and A. Rosas Jr., "A comparison of the phytosociology and dynamics of three floodplain (Várzea) forests of known ages, Rio Juruá, Western Brazilian Amazon," Botanical Journal of the Linnean Society, vol. 108, no. 3, pp. 213237, 1992.

[46] S. K. Seth and O. N. Kaul, "Tropical forest ecosystems of India: the teak forest," in Unesco, UNEP and FAO. Tropical Forest Ecosystems, pp. 628-640, Unesco-UNEP, France, 1978.

[47] S. M. Sundarapandian and P. S. Swamy, "Plant biodiversity at Lowelevation Evergreen and Moist Deciduous Forests at Kodayar in the Western Ghats," International Journal of Ecology and Environmental Science, vol. 23, no. 4, pp. 363-379, 1997. 
[48] P. Bhuyan, M. L. Khan, and R. S. Tripathi, "Tree diversity and population structure in undisturbed and human-impacted stands of tropical wet evergreen forest in Arunachal Pradesh, Eastern Himalayas, India," Biodiversity and Conservation, vol. 12, no. 8, pp. 1753-1773, 2003.

[49] C. S. Reddy, S. Babar, G. Amarnath, and C. Pattanaik, "Structure and floristic composition of tree stand in tropical forest in the Eastern Ghats of northern Andhra Pradesh, India," Journal of Forestry Research, vol. 22, no. 4, pp. 491-500, 2011.

[50] R. J. Burnham, "Dominance, diversity and distribution of lianas in Yasuní, Ecuador: who is on top?" Journal of Tropical Ecology, vol. 18, no. 6, pp. 845-864, 2002.

[51] M. Cao and J. Zhang, "Tree species diversity of tropical forest vegetation in Xishuangbanna, SW China," Biodiversity and Conservation, vol. 6, no. 7, pp. 995-1006, 1997. 

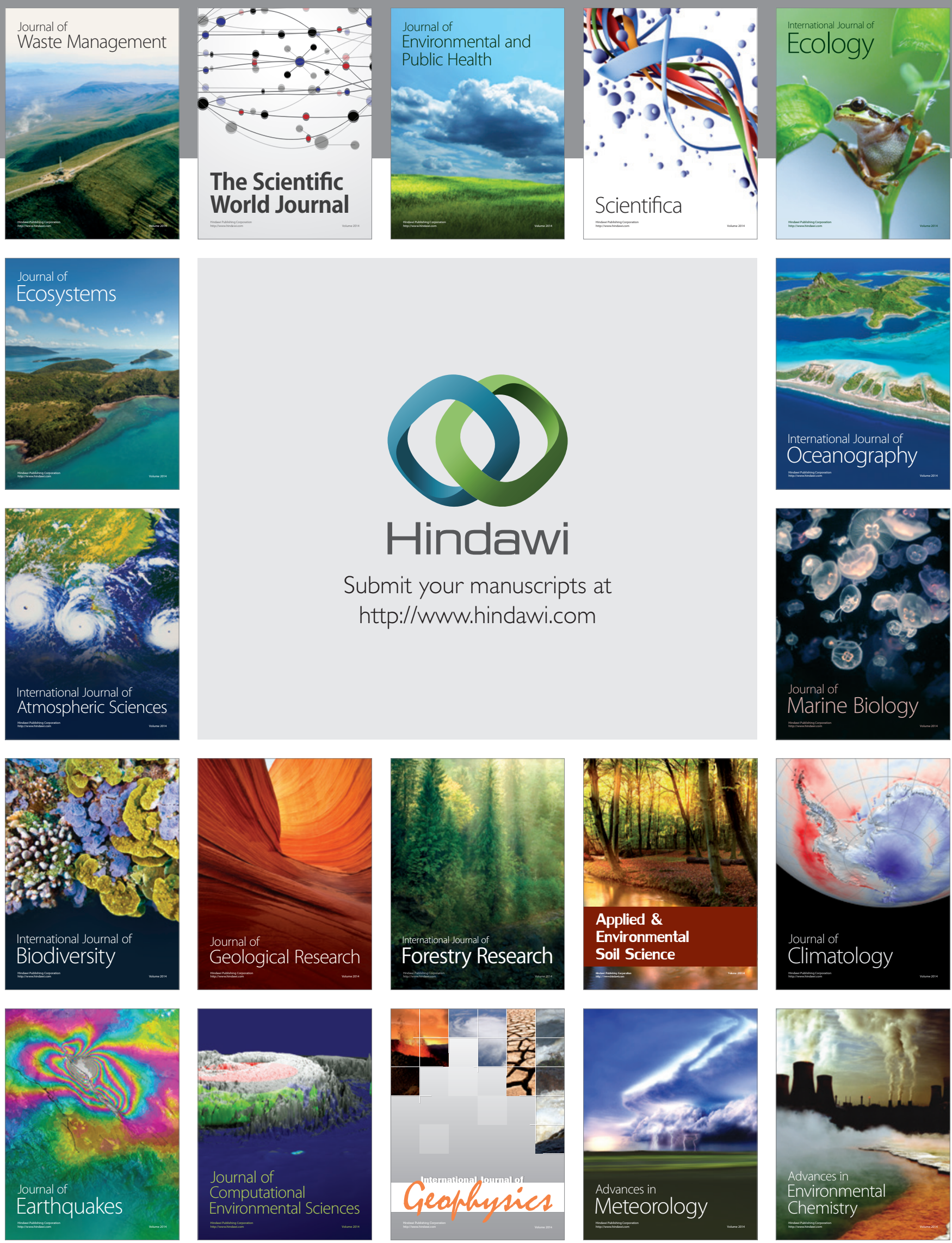